Relations industrielles

Industrial Relations

\title{
Labour Relations Statistics
}

Volume 4, numéro 9, mai 1949

URI : https://id.erudit.org/iderudit/1023972ar

DOI : https://doi.org/10.7202/1023972ar

Aller au sommaire du numéro

Éditeur(s)

Département des relations industrielles de l’Université Laval

ISSN

0034-379X (imprimé)

1703-8138 (numérique)

Découvrir la revue

Citer cet article

(1949). Labour Relations Statistics. Relations industrielles / Industrial Relations, 4(9), 89-89. https://doi.org/10.7202/1023972ar

Tous droits réservés @ Département des relations industrielles de l’Université Laval, 1949
Ce document est protégé par la loi sur le droit d'auteur. L’utilisation des services d'Érudit (y compris la reproduction) est assujettie à sa politique d'utilisation que vous pouvez consulter en ligne.

https://apropos.erudit.org/fr/usagers/politique-dutilisation/ 


\section{LABOUR RELATIONS STATISTICS}

We are pleased to give a few statistics on labour relations in the Province of Qucbec for the month of May, 1949. These statistics have been furnished through the courtesy of the Department of Labour.

1. Union recognition. - 24 requests for union recognition were presented; of this number, 6 were accepted and the necessary certificate issued in each case; 1 request was refused; 2 certificates have been revoked; 4 votes were taken.

If we take into account the 24 requests received during the month and previous requests of which no disposal had been made, in total 60 requests for certification have been considered, affecting 1,594 employees.

In addition, the Labour Relations Board referred to the Minister of Labour 36 requests for conciliation in order to help the parties complete a collective agreement. Five inquiries have been started in cases of dismissal; intimidation and lock-outs. The Board held 16 hearings.

2. Collective Agreements. - During May 1949, 38 collective agreements were deposited with the Board of which 16 were under article 19 of the Labour Relations Act and 22 in virtue of article 19-A. These agreements cover 5,165 employees - 30 agreements concern industrial establishments; 1 , commercial establisment; 5 , private services; 2 , public services.

In breaking down the agreements according to the union affiliation, we note the following results:

17 agreements concerning 2,690 employees have been deposited by unions affiliated with the Canadian and Catholic Confederation of Labour Inc.

4 agreements affecting 124 employees have been deposited by unions affiliated with the Canadian Congress of Labour.

9 agreements affecting 1,972 employees have been deposited by unions affiliated with the Trades and Labour Congress of Canada.
Finally, 5 agreements affecting 1,086 employees have been deposited by independent incorporated unions and 3, affecting 379 employees by independent unions not incorporated.

On May 31st, 1949, the statistics of the Labour Relations Board show that 1,204 collective agreements are in force affecting 190,360 employees in the Province.

3. Arbitration. - 28 Councils of Arbitration were functioning on May 1, 1949 . During the month 3 new boards were formed. During the same period 7 arbitration awards have been given. There were, therefore, on May 31st, 1949, 24 Councils of Arbitration in operation of which 5 in regard to public services and 19 in regard to private enterprises.

\section{THESIS ON INDUSTRIAL RELATIONS PRESENTED FOR THE MASTER DEGREE IN SOCIAL SCIENCES}

BELANGER, abbé Ovila, La formation professionnelle dans les centres d'apprentissage.

DION, Denys, Etude comparative des lois des syndicats professionnels de France et de Québec.

GOSSELIN, Jean-Yves, Enquête sur l'application du décret relatif à l'industrie de la boulangerie de Québec.

LIZOTTE, Jean, Monographie d'un service du personnel dans un magasin à rayon.

PEPIN, Marcel, L'organisation ouvrière dans l'industrie textile du Québec.

FOIRIER, Chs-Edouard, Etude sur le décret relatif au commerce de l'alimentation au détail de Québec.

RICARD, Louise, Monographie industrielle du centre médical de la Compagnie Dominion Corset Ltd., Québec. pratique à la Cie Limitée Dominion Corset, Québec.

SINCENNES, Aldège, Etude sur le décret du commerce de gros de l'alimentation dans la région de Québec.

THERIEN, Chs-Edouard, Les relations patronales-ouvrières dans l'industrie de la chaussure de la province de Québec.

YACCARINI, Benoit, Les tribunaux du travail. 